Article

\title{
Duck Plague Virus Promotes DEF Cell Apoptosis by Activating Caspases, Increasing Intracellular ROS Levels and Inducing Cell Cycle S-Phase Arrest
}

\author{
Chuankuo Zhao ${ }^{1,2,3,+}+\mathbb{D}_{\text {, Mingshu Wang }}{ }^{1,2,3,+}$, Anchun Cheng $1,2,3,+, * \mathbb{D}$, Qiao Yang $1,2,3$, \\ Ying Wu 1,2,3, Renyong Jia 1,2,3, Dekang Zhu 2,3 ${ }^{(D)}$, Shun Chen 1,2,3 ${ }^{\mathbb{D}}$, Mafeng Liu 1,2,3, \\ Xinxin Zhao 1,2,3, Shaqiu Zhang 1,2,3, Yunya Liu 1,2,3, Yanling Yu 1,2,3, Ling Zhang 1,2,3, \\ Bin Tian 1,3, Mujeeb Ur Rehman 1,3, Leichang Pan 1,3 and Xiaoyue Chen 2,3 \\ 1 Institute of Preventive Veterinary Medicine, Sichuan Agricultural University, Wenjiang, Chengdu 611130, \\ Sichuan, China; zck0523@163.com (C.Z.); mshwang@163.com (M.W.); yangqiao721521@sina.com (Q.Y.); \\ yingzi_no1@126.com (Y.W.); jiary@sicau.edu.cn (R.J.); shunchen@sicau.edu.cn (S.C.); \\ liumafengra@163.com (M.L.); xxinzhao@163.com (X.Z.); shaqiu86@hotmail.com (S.Z.); \\ yunnyaaliu@163.com (Y.L.); yanling3525@163.com (Y.Y.); z197451@126.com (L.Z.); btian_1985@163.com (B.T.); \\ mujeebnasar@yahoo.com (M.U.R.); p12007@126.com (L.P.) \\ 2 Key Laboratory of Animal Disease and Human Health of Sichuan Province, Sichuan Agricultural University, \\ Wenjiang, Chengdu 611130, Sichuan, China; zdk24@sicau.edu.cn (D.Z.); chenxy_24@sina.cn (X.C.) \\ 3 Avian Disease Research Center, College of Veterinary Medicine, Sichuan Agricultural University, Wenjiang, \\ Chengdu 611130, Sichuan, China \\ * Correspondence: chenganchun@vip.163.com; Tel./Fax: +86-28-86291905 \\ $\dagger$ These authors contributed equally to this work.
}

Received: 19 January 2019; Accepted: 21 February 2019; Published: 24 February 2019 updates

\begin{abstract}
Background: Duck plague virus (DPV) can induce apoptosis in duck embryo fibroblasts (DEFs) and in infected ducks, but the molecular mechanism of DPV-induced apoptosis remains unknown. Methods: We first used qRT-PCR and a Caspase-Glo assay to determine whether the caspase protein family plays an important role in DPV-induced apoptosis. Then, we used an intracellular ROS detection kit and the mitochondrial probe JC-1 to respectively detect ROS levels and mitochondrial membrane potential (MMP). Finally, flow cytometry was used to detect apoptosis and cell cycle progression. Results: In this study, the mRNA levels and enzymatic activities of caspase-3, caspase-7, caspase-8, and caspase-9 were significantly increased during DPV-induced apoptosis. The caspase inhibitors Z-DEVD-FMK, Z-LEHD-FMK, and Q-VD-Oph could inhibit DPV-induced apoptosis and promote viral replication. Subsequently, a significant decrease in MMP and an increase in the intracellular ROS levels were observed. Further study showed that pretreating infected cells with NAC (a ROS scavenger) decreased the intracellular ROS levels, increased the MMP, inhibited apoptosis, and promoted viral replication. Finally, we showed that DPV infection can cause cell cycle S-phase arrest. Conclusions: This study shows that DPV causes cell cycle S-phase arrest and leads to apoptosis through caspase activation and increased intracellular ROS levels. These findings may be useful for gaining an understanding of the pathogenesis of DPV and the apoptotic pathways induced by $\alpha$-herpesviruses.
\end{abstract}

Keywords: apoptosis; cell cycle; duck embryo fibroblast; duck plague virus; ROS

\section{Introduction}

Duck plague is an acute, contagious, and fatal disease in waterfowl (ducks and geese) caused by duck plague virus (DPV), a member of the $\alpha$-herpesvirus subfamily with a double-stranded DNA 
genome of approximately $162 \mathrm{~kb}$, and a capsid, tegument, and envelope [1-6]. Virulent DPV strains are highly pathogenic and induce massive petechial hemorrhages in parenchymal organs, lymphoid tissue, and the digestive tract; they also cause large numbers of duck deaths [7-10]. To control this disease on duck farms, attenuated DPV vaccines and DNA vaccines have been studied [11-16].

Apoptosis is an indispensable innate immune mechanism that can effectively eliminate infected cells [17]. The morphological characteristics of apoptosis include chromatin aggregation and condensation, and apoptotic body formation. Apoptosis has been shown to be induced by two classical pathways: the intrinsic and extrinsic pathways [18]. The intrinsic signaling pathway is known as mitochondria- and endoplasmic reticulum (ER)-initiated apoptosis. Mitochondria are fundamentally involved in the mitochondrial apoptosis pathway, which is regulated by numerous factors, such as members of the Bcl-2 protein family. Bcl-2 protein family members, including Bax, Bak, Bcl-2, Bcl-xl, Mcl-1, Bid, and Bim, decrease the mitochondrial membrane potential (MMP), causing the release of Cyt-c, which forms a complex with pro-caspase-9 and Apaf-1. This complex activates caspase-9, which then activates downstream caspase-3 to initiate apoptosis [19]. In cells, ER stress regulates the concentration of $\mathrm{Ca}^{2+}$ and initiates the IRE1, PERK, and ATF6 pathways, which are associated with the mitochondrial pathway of apoptosis [20,21]. Additionally, increased ROS levels accelerate apoptosis. ROS is produced by the mitochondria, which are affected by ROS levels. Increased ROS levels reduce the MMP, which induces the mitochondrial apoptosis pathway [22-24]. By contrast, the extrinsic pathway is activated by the death ligand and its corresponding receptor. Subsequently, pro-caspase- 8 is recruited to form the death-inducing signaling complex (DISC), leading to the activation of caspase-8, which activates downstream caspase- 3 to induce apoptosis $[25,26]$.

The results of many studies have revealed that the molecular mechanism of $\alpha$-herpesvirus-induced apoptosis is complicated. Moreover, previous findings have proven that $\alpha$-herpesviruses can encode many proteins that inhibit apoptosis, including Us3, Us5, ICP4, ICP22, ICP27, and LAT [18]. $\alpha$-Herpesviruses can modulate apoptosis, which plays an important role in viral replication and latent infection. The results of our previous studies have demonstrated that DPV causes apoptosis in infected ducks and duck embryo fibroblasts (DEFs) $[27,28]$, but the molecular mechanism of this activity remains unknown. The results of this study show that DPV causes cell cycle S-phase arrest and leads to apoptosis through caspase activation and increased intracellular ROS levels, providing a basis for further studies on DPV pathogenesis and the apoptotic pathways induced by $\alpha$-herpesviruses.

\section{Materials and Methods}

\subsection{Cells and Viruses}

DEFs were prepared from 9- to 11-day-old duck embryos (The farm of Sichuan Agricultural Uniersity). The cells were grown in Eagle's minimal essential medium (MEM) (Sigma, St. Louis, MO, USA) containing 10\% newborn bovine serum (NBS) (Gibco, Gaithersburg, MD, USA) at $37^{\circ} \mathrm{C}$ in a humidified incubator with $5 \% \mathrm{CO}_{2}$. The DPV CHv strain was previously isolated and characterized in our laboratory $[29,30]$. Unless otherwise stated, the median tissue culture infective dose $\left(\mathrm{TCID}_{50}\right)$ used in DEFs was 1 MOI. DEFs were infected with DPV CHv for $1 \mathrm{~h}$ at $37^{\circ} \mathrm{C}$, and were then cultured in MEM supplemented with $2 \%$ NBS.

\subsection{Cell Viability}

Cell viability was measured using an MTT assay kit (Sangon Biotech, Shanghai, China) according to the manufacturer's instructions. Briefly, the cells were seeded in 96-well plates. After pretreatment with Z-DEVD-FMK, Z-IETD-FMK, Z-LEHD-FMK, Q-VD-Oph, or NAC for $2 \mathrm{~h}$, the cells were incubated in culture medium containing MTT $\left(0.5 \mathrm{mg} \mathrm{mL}^{-1}\right)$ for $4 \mathrm{~h}$ at $37^{\circ} \mathrm{C}$. The medium was subsequently replaced with a formazan solubilization solution, and the absorbance at $570 \mathrm{~nm}$ was measured using a microplate reader. 


\subsection{Detection of $D P V$}

Viral DNA was extracted using a MiniBEST Viral RNA/DNA extraction kit (TaKaRa, Dalian, China) and then used for quantitative real-time PCR; this method is described in detail in our previously published article [31]. The following primers were generated based on the viral gene UL30: Forward primer-5'-GGACAGCGTACCACAGATAA-3', Reverse primer-5'-ACAAATCCCAAGCGTAG-3'. DPV was detected by determining the TCID 50 [32]. Briefly, serial 10-fold dilutions of the viral supernatant were made, and $100 \mu \mathrm{L}$ of each dilution was inoculated into eight wells of a 96-well microtitration plate with an appropriate cell culture monolayer. The plates were incubated for 5-7 days at $37^{\circ} \mathrm{C}$ in a $5 \% \mathrm{CO}_{2}$ atmosphere, after which the cultures were examined for cytopathology under a light microscope. The dilution of the suspension that caused cytopathology in half of the cultures $\left(\mathrm{TCID}_{50} / 0.1 \mathrm{~mL}\right.$ ) was calculated according to the method of Spearman and Kaerber.

\subsection{DAPI Staining of Cell Nuclei}

DPV-infected and control cells were collected and fixed with 4\% paraformaldehyde for $60 \mathrm{~min}$. Subsequently, the solution was permeabilized for $30 \mathrm{~min}$ and stained with DAPI for $10 \mathrm{~min}$. The nuclei were observed with a fluorescence microscope.

\subsection{Isolation of RNA and Analysis of the mRNA Expression of Apoptosis-Related Genes by qRT-PCR}

At different time points postinfection, total RNA was extracted from DPV-infected cells and mock-infected cells using RNAiso Plus (TaKaRa, Dalian, China) according to the manufacturer's instructions. The extraction yield was assessed by measuring the absorbance at $260 \mathrm{~nm}$, and RNA quality was evaluated by calculating the ratio of the absorbance at $260 \mathrm{~nm}$ to that at $280 \mathrm{~nm}$. Extracted RNA was immediately reverse-transcribed into first-strand cDNA using a PrimeScript RT Reagent kit with gDNA Eraser. For qRT-PCR, a $20 \mu \mathrm{L}$ total reaction volume containing $10 \mu \mathrm{L}$ of SYBR Premix Ex Taq II (Tli RNaseH Plus), $1 \mu \mathrm{L}$ of forward primer, $1 \mu \mathrm{L}$ of reverse primer, $6 \mu \mathrm{L}$ of RNase-free water, and $2 \mu \mathrm{L}$ of cDNA was used. The thermal cycling procedure included initial denaturation for $30 \mathrm{~s}$ at $95^{\circ} \mathrm{C}$, followed by 40 cycles of $5 \mathrm{~s}$ at $95^{\circ} \mathrm{C}$ and $30 \mathrm{~s}$ at the melting temperature of the specific primer pair. Gene expression was analyzed, and $\beta$-actin was used as the internal control. The accession numbers listed in Table 1 were obtained from NCBI GenBank. The relative gene expression was calculated using the mean values obtained with the arithmetic formula $\Delta \Delta \mathrm{Ct}$.

Table 1. Primers for qRT-PCR analysis of gene expression.

\begin{tabular}{|c|c|c|c|}
\hline Target Gene & & Primer Sequences & Gene Accession Number \\
\hline \multirow[t]{2}{*}{ Caspase-3 } & For & $5^{\prime}$ TGGTGTTGAGGCAGACAGTGGA 3' & XM_005030494 \\
\hline & Rev & $5^{\prime}$ CATTCCGCCAGGAGTAATAGCC $3^{\prime}$ & \\
\hline \multirow[t]{2}{*}{ Caspase-8 } & For & $5^{\prime}$ GGTGATGCTCGTCAGAAAGGTG 3' & XM_013094737 \\
\hline & Rev & $5^{\prime}$ AGCCATGCCCAAGAGGAAGT 3' & \\
\hline \multirow[t]{2}{*}{ Caspase-9 } & For & 5'GCTGCTTCAACTTCCTCCGTAA 3' & XM_013095294 \\
\hline & Rev & $5^{\prime}$ CATCTCCACGGACAGACAAAGG 3' & \\
\hline \multirow[t]{2}{*}{$\beta$-Actin } & For & 5' CCGGGCATCGCTGACA 3' & NM_001310421 \\
\hline & Rev & 5' GGATTCATCATACTCCTGCTTTGCT 3' & \\
\hline
\end{tabular}

\subsection{Flow Cytometric Analysis of Apoptosis}

Apoptotic cells were detected by flow cytometry (FCM). First, $5 \mu \mathrm{L}$ of Via-Probe ${ }^{\mathrm{TM}}$ (cat. no. 555816; BD Pharmingen, USA) and $5 \mu \mathrm{L}$ of Annexin-PE (BD Pharmingen) were added to $100 \mu \mathrm{L}$ of cell suspension and were incubated at $25^{\circ} \mathrm{C}$ in the dark for $15 \mathrm{~min}$. Annexin binding buffer $(450 \mu \mathrm{L})(\mathrm{BD}$ Pharmingen, USA, 51-66121E) was then added to the mixture, and the percentage of apoptotic cells was assayed by FCM within $1 \mathrm{~h}$. 


\subsection{FCM Cell Cycle Analysis}

Cell cycle analysis was performed by FCM using DPV-infected and control cells that were collected and fixed using $70 \%$ ethanol. The cells were subsequently washed with PBS twice and then incubated with $0.5 \mathrm{~mL}$ of a PI/RNASE solution for $15 \mathrm{~min}$. The cells were detected by FCM within $1 \mathrm{~h}$.

\subsection{Determination of Caspase-3, Caspase-7, Caspase-8, and Caspase-9 Activities}

The activities of caspase-3, caspase-7, caspase-8, and caspase-9 were measured using a Caspase-Glo assay kit (Promega, Madison, Wisconsin, USA) according to the manufacturer's instructions. The cells were seeded into 12-well plates and were counted with a blood cell counting plate. From each sample, approximately 20,000 cells were added to $100 \mu \mathrm{L}$ of Caspase-Glo reagent in a 96-well white-walled plate and incubated for $30 \mathrm{~min}$. Luciferase activity was detected using a multifunctional microplate reader (Thermo Scientific, Massachusetts, USA), and the fold increase in protease activity was determined by comparing the luciferase activity of the infected cells with that of mock-infected cells. In the caspase inhibitor assays, caspase inhibitors were dissolved in dimethyl sulfoxide (DMSO) and stored at $-20^{\circ} \mathrm{C}$ before use. Cells were exposed to caspase inhibitors (i.e., $20 \mathrm{mM}$ Z-DEVD-FMK, Z-IETD-FMK, Z-LEHD-FMK, and Q-VD-Oph) for $2 \mathrm{~h}$ prior to DPV infection.

\subsection{Determination of $M M P$}

MMP was measured using a JC-1 staining kit (Sigma-Aldrich, Shanghai, China) according to the manufacturer's instructions. Briefly, MEM-washed cells were stained with JC-1 dye for $20 \mathrm{~min}$. Then, the cells were observed, and the data were collected with a fluorescence microscope and a multifunctional microplate reader.

\subsection{Determination of Intracellular ROS Levels}

The intracellular ROS levels of cells were measured using an intracellular ROS detection kit (Sigma-Aldrich) according to the manufacturer's instructions. Briefly, the cells were inoculated into a 96-well microtitration plate, $100 \mu \mathrm{L}$ of ROS detection reagent mixture was added, and the plate was incubated for $1 \mathrm{~h}$ at $37^{\circ} \mathrm{C}$ in a $5 \% \mathrm{CO}_{2}$ humidified incubator. Subsequently, the data were collected using a fluorescence microscope and a multifunctional microplate reader.

\subsection{Statistical Analysis}

The data were assessed using GraphPad Prism 6, and statistical significance was assessed using Student's $t$-test. The data are presented as the means $\pm \mathrm{SD} ;{ }^{*} p<0.05$ and ${ }^{* *} p<0.01$ indicate significance compared with the control.

\section{Results}

\subsection{Cytopathic Effects (CPEs) Induced by DPV in DEFs}

First, the morphological changes in DPV-infected DEFs were determined by microscopic observations 12, 24, 36, 48, and $60 \mathrm{~h}$ postinfection (hpi) (Figure 1A). At 36, 48, and $60 \mathrm{hpi}$, compared with the morphology of the control cells, obvious cellular fragmentation and plaques were observed in the DPV-infected DEFs. The arrows indicate that the infected cells appeared with CPEs at 24, 36, 48, and 60 hpi. 4',6-Diamidino-2-phenylindole (DAPI) staining was performed to observe the morphological changes of the cell nuclei (Figure 1B), and syncytia were present at 36 and 48 hpi in the DPV-infected cells, which is denoted by arrowheads. The above observations showed that DPV causes CPEs in DEFs. In addition, DAPI staining at 24, 36, 48, and 60 hpi revealed the presence of apoptosis-associated morphological changes, such as nuclear fragmentation and apoptotic bodies. At $24,36,48$, and $60 \mathrm{hpi}$, the arrows indicate that the nuclei of infected cells appear as marginated typical apoptotic bodies. We used quantitative real-time PCR [31] and median tissue culture infective dose 
$\left(\mathrm{TCID}_{50}\right)$ assays to detect DPV (Figure 1C,D); the results show that the viral DNA and titers gradually increased as the infection progressed.

A
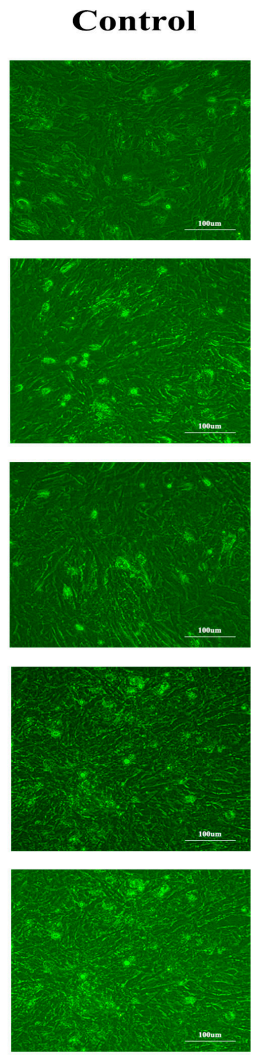

C

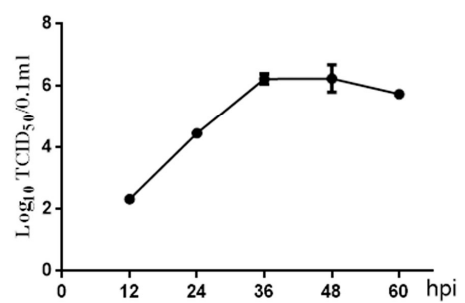

B
Control
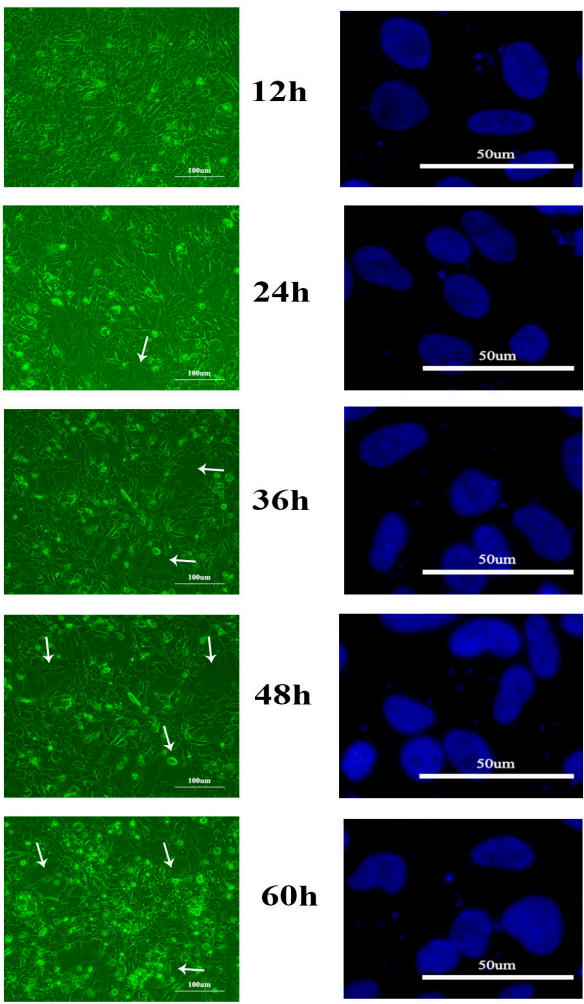

D

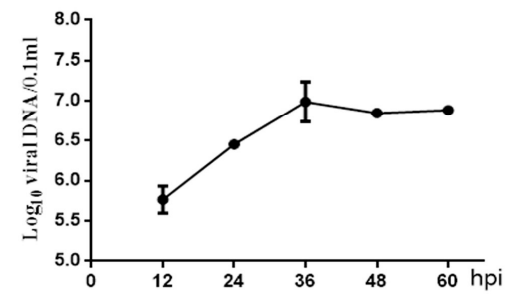

$12 h$

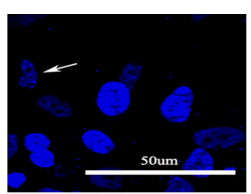

24h

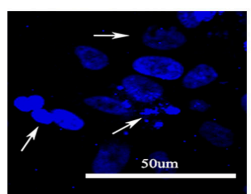

$36 h$

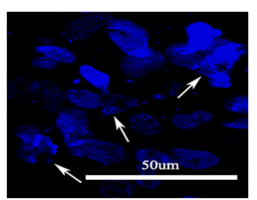

$48 h$

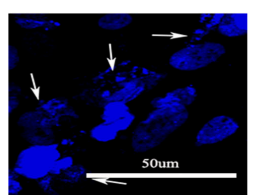

$60 h$

Figure 1. Cytopathic effects (CPEs) induced by duck plague virus (DPV) in duck embryo fibroblasts (DEFs). (A) Cellular morphological changes in cells infected with DPV for the indicated number of hours. At 24, 36, 48, and $60 \mathrm{hpi}$ (hours postinfection), the arrows indicate that infected cells appeared to have cellular fragmentation and plaques. (B) Nuclear morphological changes in cells infected with DPV for the indicated number of hours. At 24, 36, 48, and $60 \mathrm{hpi}$, the arrows indicate that nuclei of infected cells appear appeared as fragmented and marginated typical apoptotic bodies. (C) Viral titers were determined at the indicated time points by measuring the TCID 50 for the DEFs. All titrations were carried out in three independent experiments. The titers obtained were averaged, and the standard error of the mean was calculated for each time point. (D) Quantitative analysis of viral DNA by quantitative real-time PCR assay. Viral DNA detection was carried out in three independent experiments. The titers obtained were averaged, and the standard error of the mean was calculated for each time point.

\subsection{Effect of DPV Infection on Caspases}

Next, we determined whether the caspase protein family plays an important role in DPV-induced apoptosis. The mRNA levels of caspase-3, caspase-7, caspase-8, and caspase- 9 were detected by 
qRT-PCR. As shown in Figure 2A, compared with control cells, DPV-infected cells exhibited significant increase in caspase-3 and caspase- 9 mRNA levels at 12, 24, 36, 48, and 60 hpi, while the caspase-7 mRNA level was significantly increased at 12, 24, 36, and 48 hpi in the infected cells. Compared with the control cells, the infected cells exhibited significant increases in the caspase-8 mRNA level at 24, 36, 48 , and 60 hpi. The results in Figure 2B show that caspase- 8 activity was significantly higher in infected cells than in control cells at 48 and $60 \mathrm{hpi}$, and caspase- 3 and caspase-7 activities were significantly higher in infected cells than in control cells at 12, 24, 36, 48, and 60 hpi. Furthermore, caspase-9 activity was significantly higher in infected cells than in control cells at 24, 36, 48, and 60 hpi.

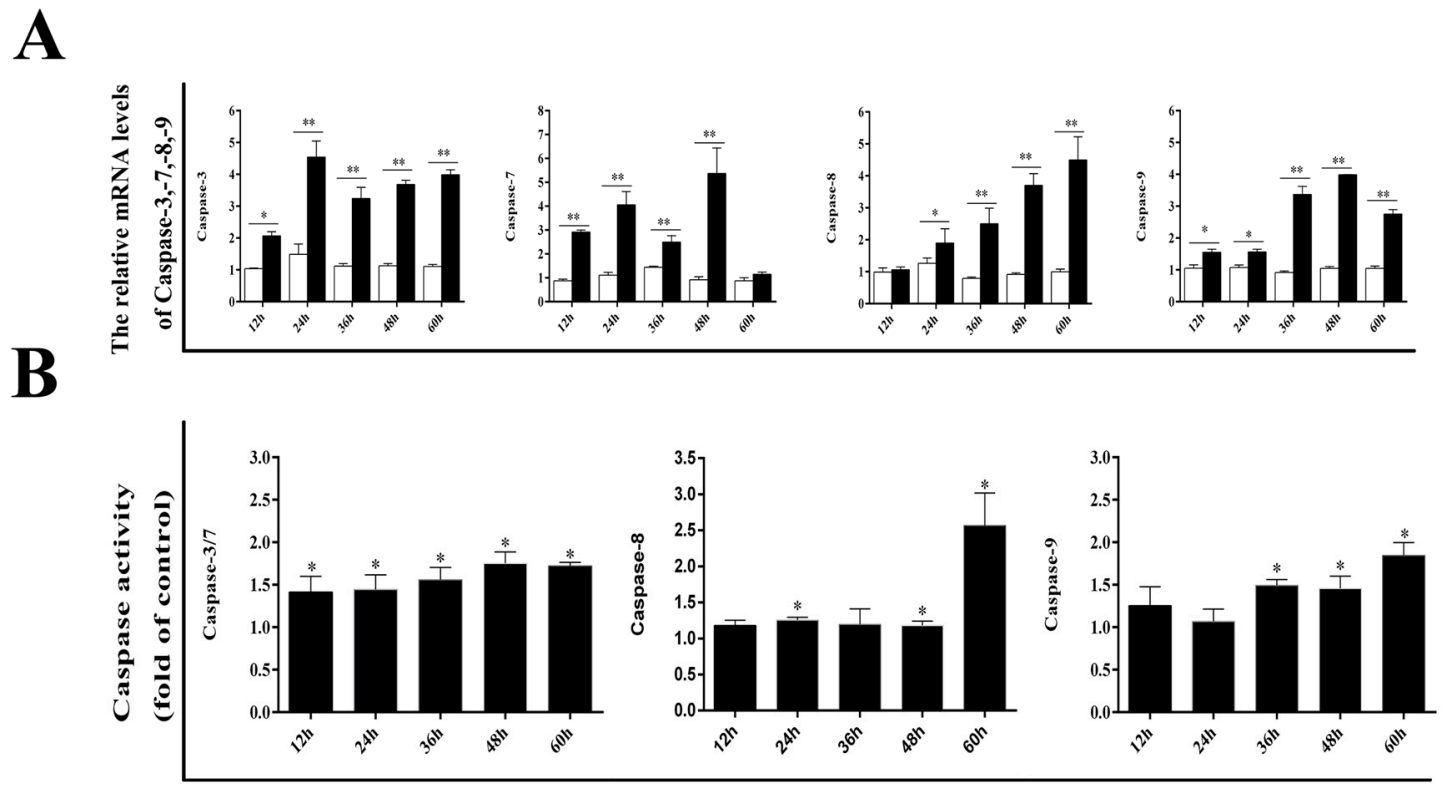

Figure 2. Effects of DPV infection on the caspase family. (A) mRNA expression levels of caspase-3, caspase-7, caspase-8, and caspase-9. (B) Activities of caspase-3, caspase-7, caspase-8, and caspase-9. The data are presented as the means \pm SD of three independent experiments. ${ }^{*} p<0.05$ and ${ }^{* *} p<0.01$, compared with the control group.

\subsection{Caspase Inhibitors Inhibit DPV-Induced Apoptosis and Promote Viral Replication}

To further assess the role of the caspase protein family in apoptosis, the effects of Z-DEVD-FMK, Z-IETD-FMK, and Z-LEHD-FMK (specific inhibitors of caspase-3, caspase-8, and caspase-9, respectively), and the pan-caspase inhibitor Q-VD-Oph were determined. Cells that were pretreated with Z-DEVD-FMK, Z-IETD-FMK, Z-LEHD-FMK, and Q-VD-Oph for $2 \mathrm{~h}$ and detected at $48 \mathrm{~h}$ showed no signs of cytotoxicity (Figure 3A,B). Cells were also pretreated with Z-DEVD-FMK, Z-IETD-FMK, Z-LEHD-FMK, and Q-VD-Oph for $2 \mathrm{~h}$ and infected with DPV. At $36 \mathrm{hpi}$, Z-DEVD-FMK and Z-LEHD-FMK inhibited DPV-induced apoptosis (Figure 3D,E), while at 48 hpi, Q-VD-Oph but not Z-IETD-FMK inhibited DPV-induced apoptosis (Figure 3D,E). Finally, we assessed the effect of Z-DEVD-FMK, Z-LEHD-FMK, Z-IETD-FMK, and Q-VD-Oph on viral replication. The results in Figure $3 C$ show that Z-DEVD-FMK and Q-VD-Oph effectively promoted viral replication, whereas Z-LEHD-FMK and Z-IETD-FMK had a weak effect on viral replication. 
A

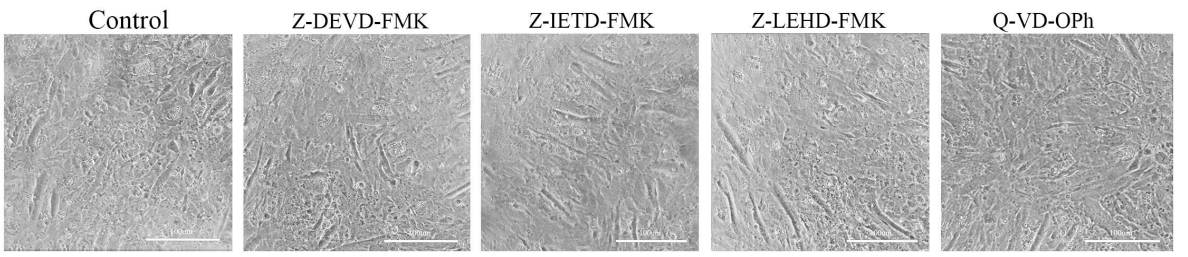

B

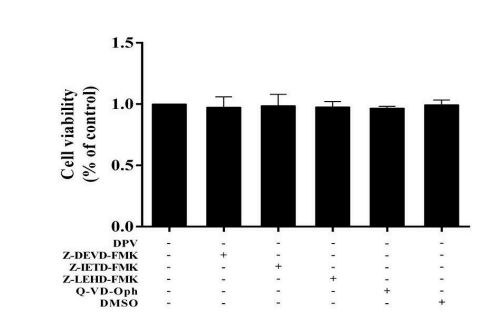

C

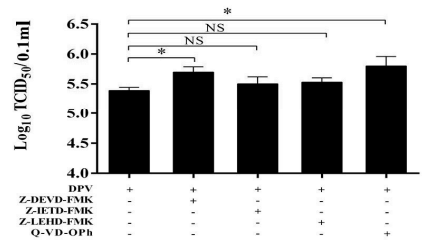

D

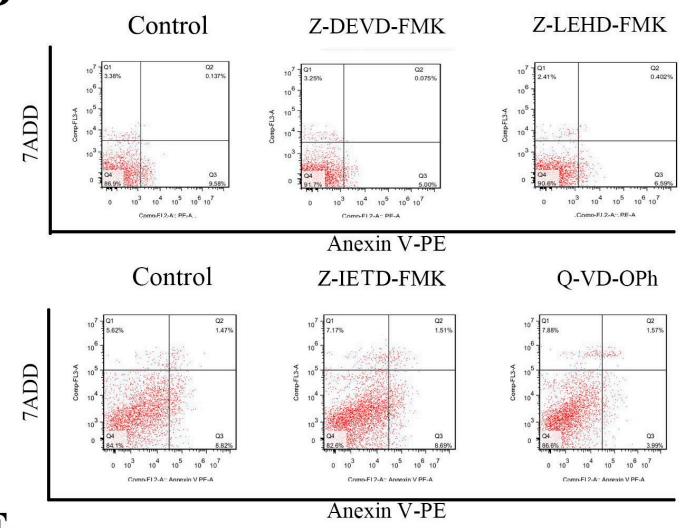

$\mathbf{E}$

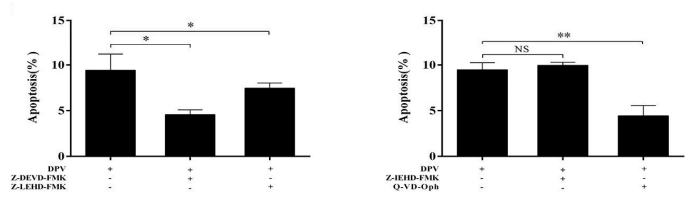

Figure 3. Z-IEHD-FMK, Z-DEVD-FMK, Z-IETD-FMK, and QVD-P-Oh inhibit apoptosis induced by DPV. (A) Cellular morphological changes following treatment with Z-IEHD-FMK, Z-DEVD-FMK, Z-IETD-FMK, and QVD-P-Oh for $2 \mathrm{~h}$ and detected at $48 \mathrm{~h}$. (B) Changes in DEF viability following treatment with Z-IEHD-FMK, Z-DEVD-FMK, Z-IETD-FMK, and QVD-P-Oh for $2 \mathrm{~h}$ were measured using an MTT assay kit at $48 \mathrm{~h}$. (C) DEF cells were pretreated with inhibitors for $2 \mathrm{~h}$ and then infected with DPV for $48 \mathrm{~h}$. After incubation, the viruses were collected, and the viral titers were determined and presented as $\log 10 \mathrm{TCID}_{50} / \mathrm{mL}$. (D) DEFs were pretreated with Z-IEHD-FMK or Z-DEVD-FMK for $2 \mathrm{~h}$ and then infected with DPV for $36 \mathrm{~h}$. DEFs were pretreated with Z-IETD-FMK or QVD-P-Oh for $2 \mathrm{~h}$ and then infected with DPV for $48 \mathrm{~h}$. Apoptosis was detected by FCM. (E) Histogram of the percentage of apoptotic cells; DEFs were pretreated with Z-IEHD-FMK or Z-DEVD-FMK for $2 \mathrm{~h}$ and then infected with DPV for $36 \mathrm{~h}$. DEFs were pretreated with Z-IETD-FMK or QVD-P-Oh for $2 \mathrm{~h}$ and then infected with DPV for $48 \mathrm{~h}$. The data are presented as the means \pm SD of three independent experiments. ${ }^{*} p<0.05$ and ${ }^{* *} p<0.01$, compared with the control group.

\subsection{Effect of DPV Infection on ROS}

To determine which apoptotic pathway is induced by DPV, an intracellular ROS detection kit was used to assess ROS production in DPV-infected cells. The results presented in Figure 6A show that at 2, 4, 12, 24 and $36 \mathrm{hpi}$, red fluorescence was stronger in the DPV-infected cells than in the control cells, while this fluorescence began to weaken at $48 \mathrm{hpi}$ (Figure $4 \mathrm{~A}$ ). The red fluorescence value observed for DPV-infected cells was significantly higher than that of the control cells at 2, 4, 12, 24, and 36 hpi but was not significantly different from that of the control cells at $48 \mathrm{hpi}$ (Figure $4 \mathrm{~B}$ ). 
A

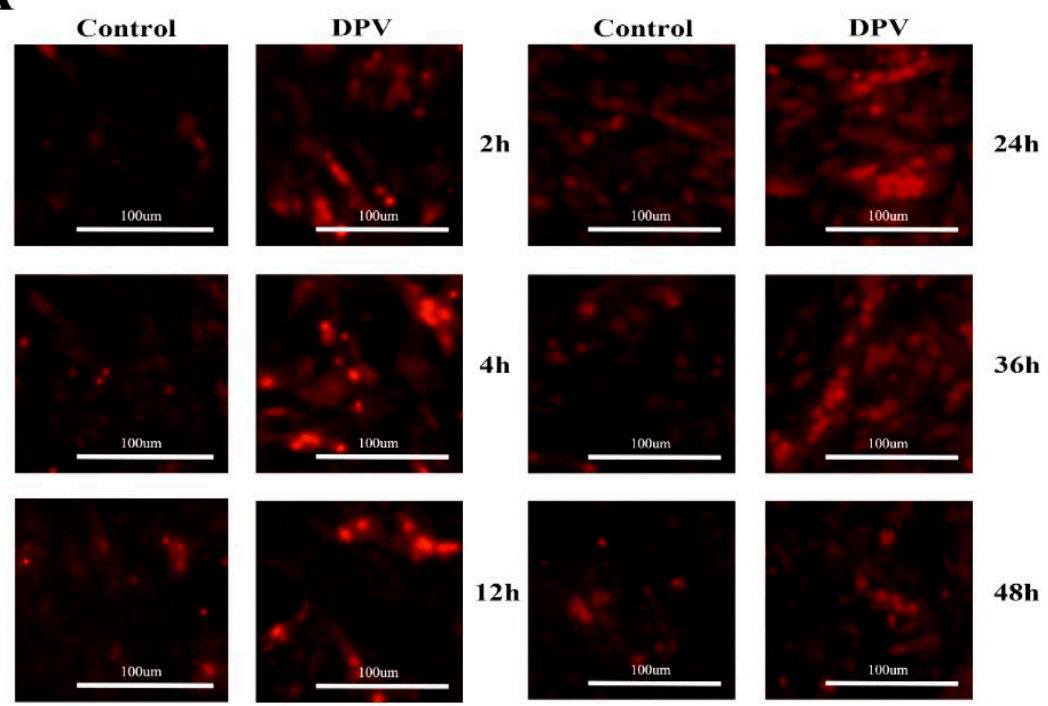

B

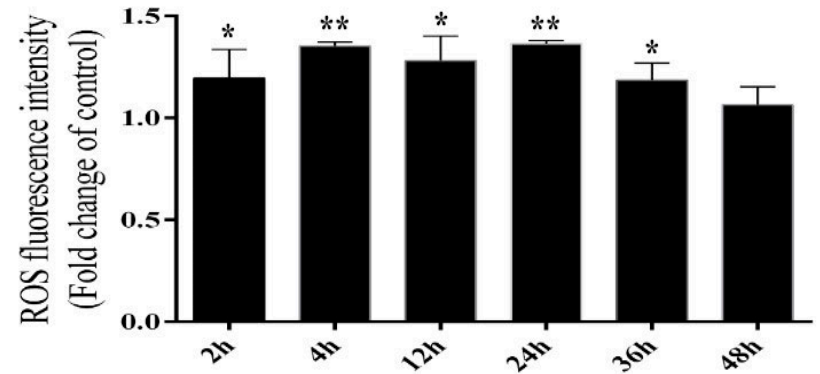

Figure 4. Determination of ROS levels in DEFs. (A) Assessment of ROS levels in DEFs using an intracellular ROS detection kit and fluorescence microscopy; the red color indicates intracellular ROS. (B) Assessment of ROS levels in DEFs using an intracellular ROS detection kit and a multifunctional microplate reader. The data are presented as the means \pm SD of three independent experiments. ${ }^{*} p<0.05$ and ${ }^{* *} p<0.01$, compared with the control group.

\subsection{Effect of DPV Infection on MMP}

ROS are produced by the mitochondria, which are affected by ROS levels. Increased ROS levels reduce the MMP, which induces the mitochondrial apoptosis pathway. To assess the changes in the MMP induced by DPV, the mitochondrial JC-1 probe was used. In normal cells, where the MMP is high, JC-1 aggregates in the mitochondria, forming polymers and emitting red fluorescence. By contrast, in apoptotic cells, where the MMP is reduced, JC-1 cannot aggregate in the mitochondria and remains in the monomeric form, emitting green fluorescence. The fluorescence microscopy results showed that compared with the control cells, the green fluorescence in DPV-infected DEFs was significantly increased (Figure 5A). The JC-1 aggregate to monomer ratio was significantly lower in the DPV-infected DEFs than in the control cells (Figure 5B). From these results, we concluded that DPV induces apoptosis in DEFs, leading to a decrease in MMP. 


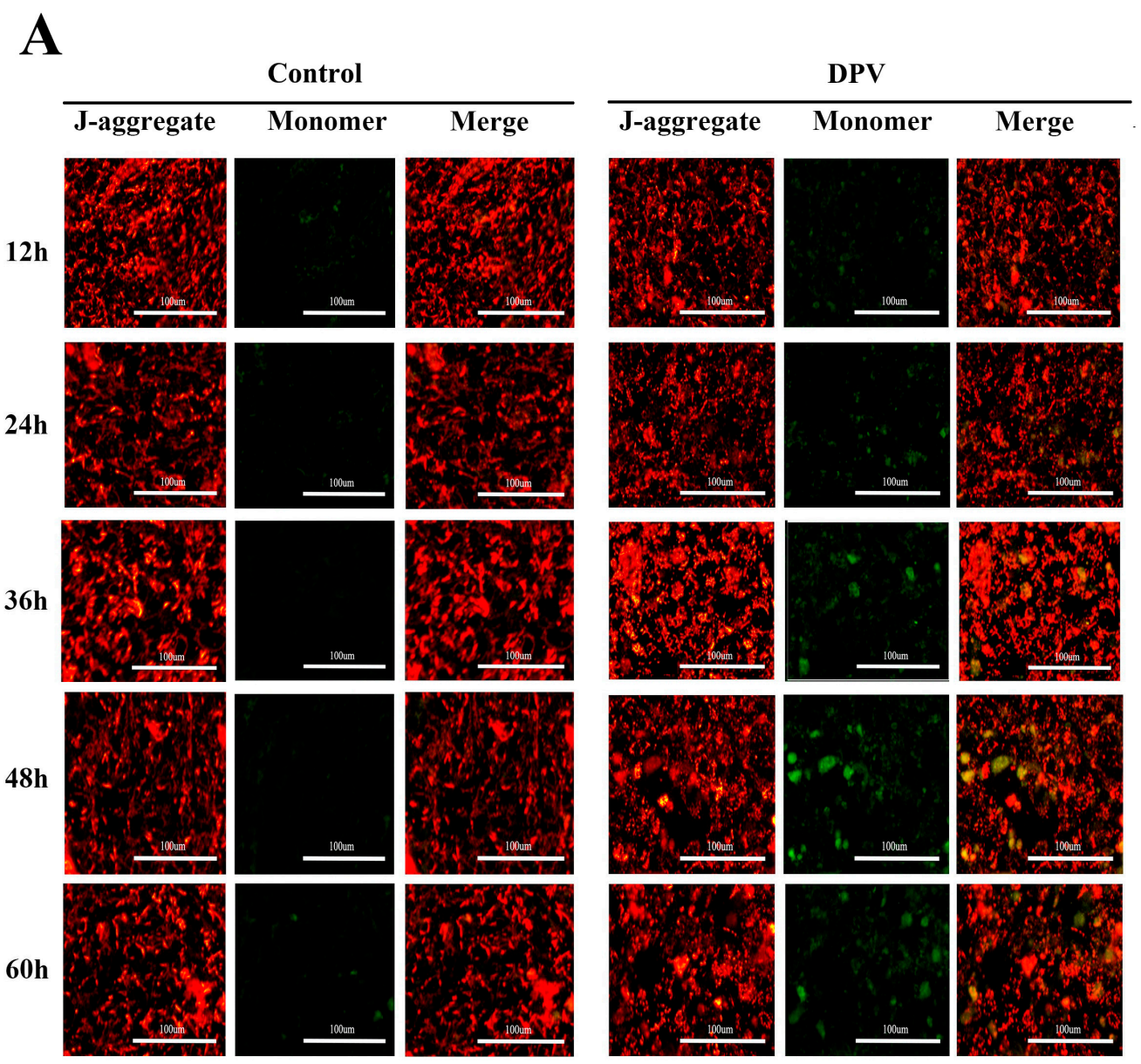

\section{B}

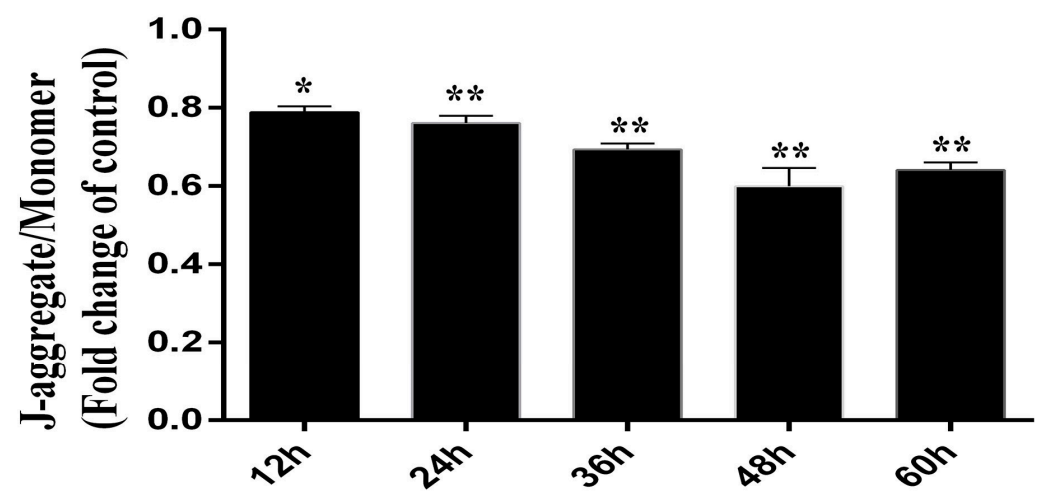

Figure 5. Mitochondrial membrane potential (MMP) determination in DEFs. (A) Assessment of DEF MMP through JC-1 staining and fluorescence microscopy. Mitochondria with normal membrane potential are indicated in red, and mitochondria with reduced membrane potential are indicated in green. (B) Assessment of DEF MMP though JC-1 staining and a multifunctional microplate reader. The data are presented as the means \pm SD of three independent experiments. ${ }^{*} p<0.05$ and ${ }^{* *} p<0.01$, compared with the control group.

3.6. NAC Scavenges Intracellular ROS, Increases the MMP, Inhibits Apoptosis and Promotes Viral Replication

To further assess the role of ROS in the apoptotic process, we evaluated the MMP and apoptosis in cells treated with NAC. The cells pretreated with 5 or $10 \mathrm{mM} \mathrm{NAC}$ for $2 \mathrm{~h}$ and detected at $36 \mathrm{~h}$ showed no signs of cytotoxicity (Figure 6A), and in the DPV-infected cells, NAC scavenged ROS (Figure 6B), 
increased the MMP (Figure 6C), and inhibited apoptosis (Figure 6E). Apoptosis is an immune defense mechanism of host cells, and because NAC can inhibit the apoptosis induced by DPV, treating cells with NAC can promote viral replication (Figure 6D).

\section{A}

\section{B}
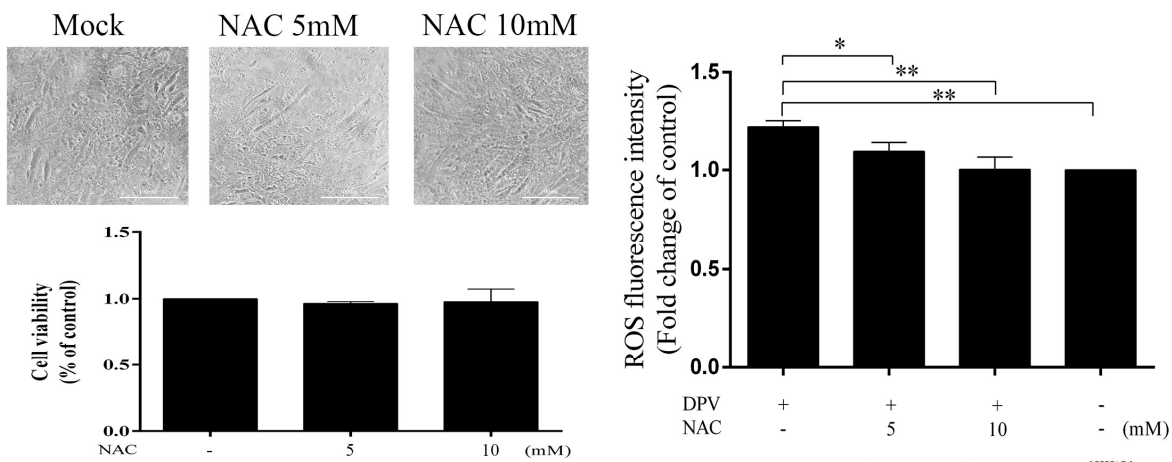

C

D
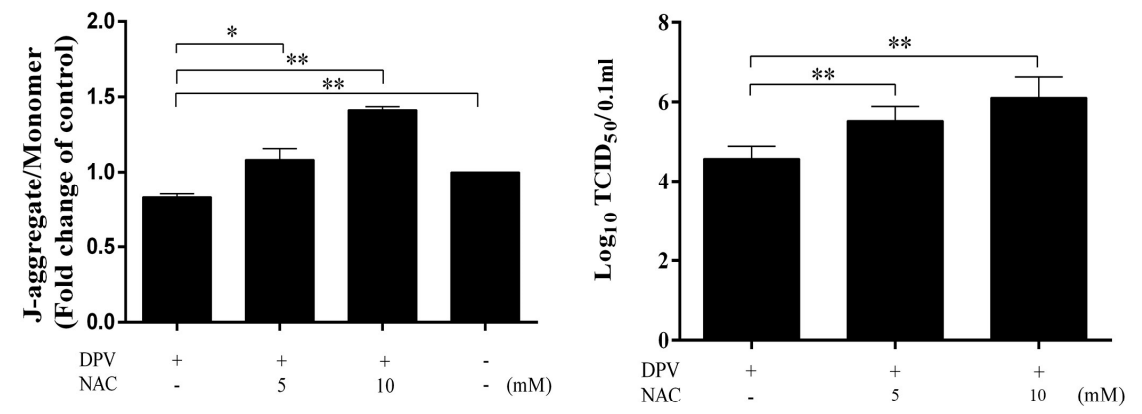

$\mathbf{E}$

DPV

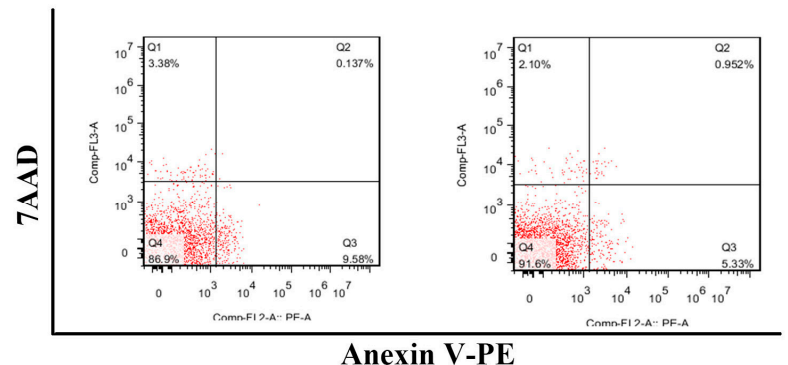

$\mathrm{DPV}+\mathrm{NAC}$

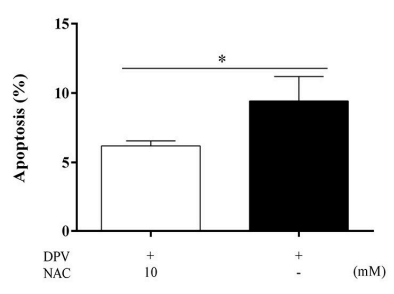

Figure 6. The ROS scavenger NAC reduces ROS levels, increases the MMP, and inhibits apoptosis. (A) Changes in cell viability following DEF pretreatment with 5 or $10 \mathrm{mM} \mathrm{NAC}$ for $2 \mathrm{~h}$ and detected by MTT assay at 36 h. (B) Pretreatment with 5 or 10 mM NAC decreased ROS in DPV-infected cells; uninfected cells were used as a control. (C) NAC (5 or $10 \mathrm{mM}$ ) increased the MMP in DPV-infected cells; uninfected cells were used as a control. (D) NAC (5 or $10 \mathrm{mM})$ promoted viral replication. (E) NAC (10 mM) inhibited apoptosis induced by DPV. The data are presented as the means \pm SD of three independent experiments. ${ }^{*} p<0.05$ and ${ }^{* *} p<0.01$, compared with the control group. 


\subsection{DPV Induces DEF S-Phase Cell Cycle Arrest}

FCM was used to assess the effect of DPV on cell cycle distribution. At 24 and 36 hpi, DPV-infected DEFs showed a significant decrease in the percentage of DEFs in the G0/G1-phase compared with the control cells, while the percentage of DEFs in the S-phase was significantly increased. In addition, the percentage of DEFs in the G2/M-phase was significantly decreased at $36 \mathrm{hpi}$, but this percentage was not different from that of the control cells at 24 hpi (Figure 7). Our results suggest that DPV causes S-phase arrest.

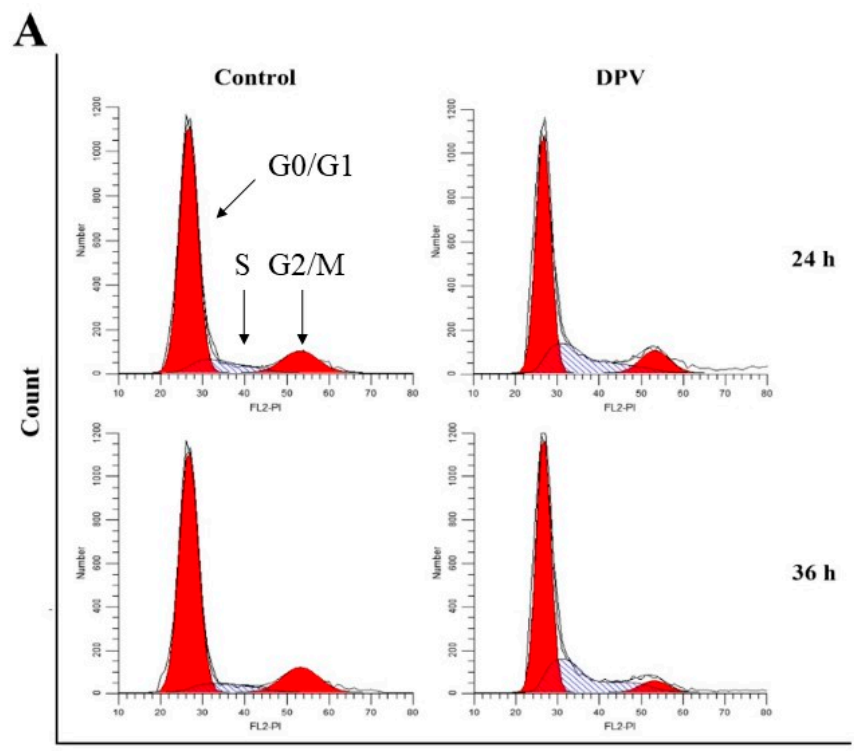

Relative DNA content

B

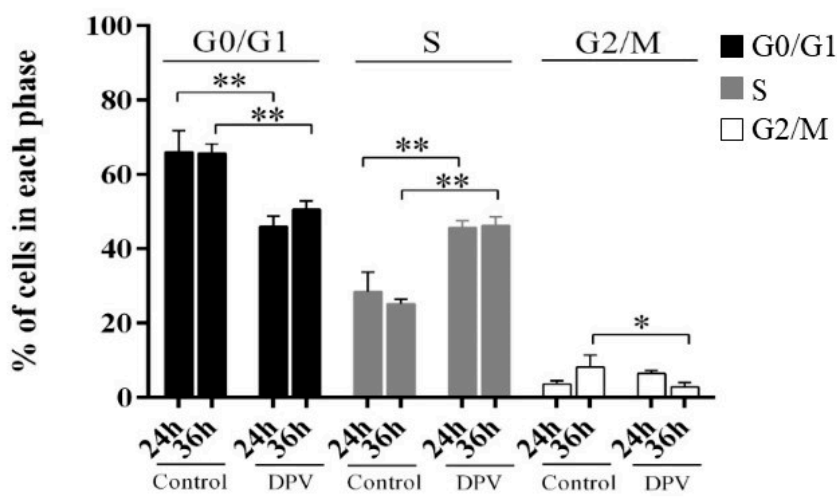

Figure 7. DPV induces cell cycle arrest at the S-phase. (A) DEFs were mock-infected (control) or infected with DPV. Cells were collected postinfection (p.i.) at the times indicated for FACS analysis of the cell cycle. (B) Histogram of the percentage of DEFs in the G0/G1-, S-, and G2/M-phases of the cell cycle, with the percentage of cells in each phase of the cell cycle shown. The data are presented as the means $\pm \mathrm{SD}$ of three independent experiments. ${ }^{*} p<0.05$ and ${ }^{* *} p<0.01$, compared with the control group.

\section{Discussion}

Many studies have shown that $\alpha$-herpesviruses can induce cell-specific apoptosis. In herpes simplex virus (HSV)-1-infected brain and skin cells, the virus can cause apoptosis in skin cells but not in brain cells [33]. Both lymphocytes and bovine kidney epithelial (MDBK) cells undergo apoptosis after being infected with BHV-1, but apoptosis does not occur in BHV-1-infected trigeminal nerves [34]. Our laboratory has discovered that DPV can induce apoptosis in the thymic, splenic, and pancreatic lymphocytes of adult ducks, and that it can cause apoptosis in DEFs in vitro [27,28]. However, there 
are large gaps in knowledge regarding the molecular mechanism of DPV-induced apoptosis. Although the molecular mechanism of $\alpha$-herpesvirus-induced apoptosis has been studied, the understanding of this mechanism is incomplete. Previous studies have shown that $\alpha$-herpesviruses induce apoptosis through the death receptor, and mitochondrial, ROS, P53, MAPK, and TLR signaling pathways [35-38]. The results of this study showed, for the first time, that DPV can induce cell cycle S-phase arrest and apoptosis through caspase activation and increased intracellular ROS levels. Further study of the apoptosis pathway induced by $\alpha$-herpesviruses will provide additional helpful information.

The caspase protein family plays a major role in the process of cell apoptosis, with caspase-9 and caspase- 8 being involved in the mitochondrial and death receptor pathways, respectively, which activate downstream caspase-3 to induce apoptosis. In this study, DPV was observed to activate caspase-3, caspase-7, caspase-8, and caspase- 9 , as evidenced by their increased mRNA levels and activities. For other $\alpha$-herpesviruses, HSV-1 infection in mononuclear cells activates caspase-9 and induces apoptosis. Xu et al. [39] studied the molecular mechanism of BHV-1-induced apoptosis and observed that Cyt-c was released into the cytoplasm from the mitochondria to activate caspase-9-induced apoptosis. In this study, we assessed the effects of the caspase-3-, caspase-8-, and caspase-9- specific inhibitors Z-DEVD-FMK, Z-IETD-FMK, and Z-LEHD-FMK, and the pan-caspase inhibitor Q-VD-Oph, on DPV-infected cells. The results showed that cells treated with the specific inhibitors for caspase- 3 and caspase- 9 and the pan-caspase inhibitor had impaired DPV-induced apoptosis, whereas the caspase-8-specific inhibitor did not induce these effects. These results suggest that caspase-3, caspase-7, and caspase-9 play a substantial role in DPV-induced apoptosis but that caspase- 8 has a lesser role in this process. Xu et al. [39] showed that in BHV-1-infected MDBK cells, the protein levels of Fas and FasL increased over time and in a BHV-1 dose-dependent manner, as did the activity of caspase- 8 , which is consistent with our results. Although our results showed that caspase- 8 played a small role in DPV-induced apoptosis, we speculated that DPV-induced apoptosis may be facilitated through the death receptor pathway.

DPV, BHV-1, HSV-1, and HSV-2 all belong to the $\alpha$-herpesviruses subfamily and share a number of characteristics. The interplay between ROS and BHV-1, HSV-1, or HSV-2 in various cell cultures has been extensively studied [40-42]. Based on the results of previous studies, we inferred that cellular ROS are broadly regulated by $\alpha$-herpesviruses in a cell- and virus-specific manner, e.g., HSV-1 infection of murine microglial cells and neural cells increased ROS levels at 24-72 and 1-24 hpi, respectively [40,42]. The HSV-2-induced production of ROS in RAW246.7 cells could be notably detected at 1 hpi [43]. In addition, increased ROS levels in DEFs infected with BHV-1 were previously detected at 1-12 hpi [44]. In this study, increased ROS levels in DEFs infected with DPV were detected at 2-24 hpi. HSV infection has been shown to result in the loss of MMP and to decrease levels of cellular ATP at the late stage of infection [45]. BHV-1 infection in MDBK cells caused mitochondria dysfunction as demonstrated by mitochondrial depolarization and reduced ATP levels during the late stage of infection [44], although the role of ROS in these adverse effects has yet to be elucidated. Since mitochondria generate ROS and because increased levels of ROS can lower the MMP, it is unsurprising that mitochondria are a potential target of some viruses that are able to induce excessive ROS. The results of our study showed that DPV infects DEFs, leading to a decrease in MMP. Importantly, by treating cells with NAC, a ROS scavenger, we observed that DPV promotes ROS production in the early stage of infection, inhibiting the decrease in MMP. We also showed that NAC can inhibit apoptosis induced by DPV. However, the HSV-1 ICP27 protein is a multifunctional protein that induces apoptosis through the mitochondrial pathway. In addition, ICP27 also increases intracellular ROS levels and participates in mitochondrial pathway-induced apoptosis [46]. As noted previously, BHV-1-infected cells also exhibit increased ROS levels during the early stage of infection, and NAC can inhibit the reduction in MMP caused by BHV-1, which is consistent with the DPV results $[39,44]$. 
In this study, we observed a reduction in G0/G1-phase cells and an increase in S-phase cells $24 \mathrm{~h}$ after DEFs were infected with DPV, while fewer G2/M-phase cells were observed at 36 hpi, showing that DPV can cause S-phase arrest. Previous studies demonstrated that an $\alpha$-herpesvirus infection can result in cell cycle arrest. By treating serum-starved cells with a mutated HSV strain that expresses only ICP0, it was previously shown that cells fail to enter into the S-phase after the addition of serum. Experiments synchronizing Hep2 cells transfected with ICP0-encoding plasmids showed that prior to transfection, these cells appeared to be arrested at the G1-phase of the cell cycle. However, following transfection with ICP0, the cells synchronized at the G2-phase when they would generally be delayed at the G2/M-phase [47-49]. CapHV-1, which infects peripheral blood mononuclear cells (PBMCs), can arrest cells at the G0/G1-phase, and CapHV-1 (caprine herpesvirus-1) significantly induces apoptosis during this stage [50]. As noted in research on Marek's disease virus (MDV), which is from the same genus as DPV, chicken embryo fibroblasts (CEFs) undergo S-phase cell cycle arrest when infected with MDV, and MDV-encoded tegument VP22 plays an important role in the blocking process, which is consistent with the results of this study with DPV [51]. In summary, we further showed that $\alpha$-herpesviruses can dynamically cause cell cycle arrest, although the mechanism of this activity may vary among different types of cells.

The results of this study showed that DPV causes S-phase cell cycle arrest and increases intracellular ROS levels, the latter of which decreases the MMP and induces apoptosis. Furthermore, caspase-3, caspase-7, caspase-8, and caspase-9 are involved in DPV-induced apoptosis, suggesting that DPV depends on the caspase protein family to induce apoptosis.

Author Contributions: Conceptualization, C.Z., M.W. and A.C.; Data curation, C.Z., M.W. and A.C.; Formal analysis, C.Z., M.W. and A.C.; Funding acquisition, M.W. and A.C; Investigation, M.W. and A.C.; Methodology, C.Z., M.W. and A.C.; Project administration, M.W. and A.C.; Resources, C.Z., M.W. and A.C.; Software, C.Z., M.W. and A.C.; Supervision, M.W. and A.C.; Validation, C.Z., M.W. and A.C.; Visualization, C.Z., M.W. and A.C.; Writing-original draft, C.Z., M.W. and A.C.; Writing—review \& editing, C.Z., M.W. and A.C., Q.Y., Y.W., R.J., D.Z.; S.C., M.L., X.Z., S.Z., Y.L., Y.Y., L.Z., B.T., M.U.R., L.P., X.C.

Funding: This research was supported by the National Key Research and Development Program of China (2017YFD0500800), China Agricultural Research System (CARS-42-17) and Sichuan Veterinary Medicine and Drug Innovation Group of China Agricultural Research System (CARS-SVDIP).

Acknowledgments: We thank Di Sun, Tianqiong He, and Hua Li for technical assistance.

Conflicts of Interest: The authors declare no competing interests.

\section{References}

1. Anchun, C.; Mingshu, W.; Ming, W.; Weiguang, Z.; Yufei, G.; Renyong, J.; Chao, X.; Guiping, Y.; Yicheng, L. Construction of duck enteritis virus gene libraries and discovery, cloning and identification of viral nucleocapsid protein gene. Chin. High Technol. Lett. 2006, 16, 948-953.

2. Yuan, G.P.; Cheng, A.C.; Wang, M.S.; Liu, F.; Han, X.Y.; Liao, Y.H.; Xu, C. Electron microscopic studies of the morphogenesis of duck enteritis virus. Avian Dis. 2005, 49, 50-55. [CrossRef] [PubMed]

3. Wu, Y.; Cheng, A.; Wang, M.; Zhu, D.; Jia, R.; Chen, S.; Zhou, Y.; Chen, X. Comparative genomic analysis of duck enteritis virus strains. J. Virol. 2012, 86, 13841-13842. [CrossRef] [PubMed]

4. Wu, Y.; Cheng, A.; Wang, M.; Yang, Q.; Zhu, D.; Jia, R.; Chen, S.; Zhou, Y.; Wang, X.; Chen, X. Complete genomic sequence of chinese virulent duck enteritis virus. J. Virol. 2012, 86, 5965. [CrossRef] [PubMed]

5. Qi, X.; Yang, X.; Cheng, A.; Wang, M.; Zhu, D.; Jia, R.; Luo, Q.; Chen, X. Intestinal Mucosal Immune Response against Virulent Duck Enteritis Virus Infection in Ducklings. Res. Vet. Sci. 2008, 87, 218-225. [CrossRef] [PubMed]

6. Guo, Y.; Cheng, A.; Wang, M.; Zhou, Y. Purification of anatid herpesvirus 1 particles by tangential-flow ultrafiltration and sucrose gradient ultracentrifugation. J. Virol. Methods 2009, 161, 1-6. [CrossRef] [PubMed]

7. Qi, X.F.; Yang, X.Y.; Cheng, A.C.; Wang, M.; Zhu, D.; Jia, R. The pathogenesis of duck virus enteritis in experimentally infected ducks: A quantitative time-course study using TaqMan polymerase chain reaction. Poult. Sci. 2008, 87, 1768-1772. 
8. Qi, X.; Yang, X.; Cheng, A.; Wang, M.; Zhu, D.; Jia, R. Quantitative analysis of virulent duck enteritis virus loads in experimentally infected ducklings. Avian Dis. 2008, 52, 338-344. [PubMed]

9. Guiping, Y.; Anchun, C.; Mingshu, W.; Yi, Z.; Fei, L.; Yufei, G.; Xiaoying, H.; Yonghong, L.; Chao, X.; Weiguang, Z.; et al. Ultrastructural pathological observation on ducks infected expeimentally with duck enteritis virus. Chin. J. Vet. Sci. 2005, 25, 459-462.

10. Anchun, C. Duck Plague; China Agriculture Press: Beijing, China, 2015.

11. Yang, X.; Qi, X.; Cheng, A.; Wang, M.; Zhu, D.; Jia, R.; Chen, X. Intestinal mucosal immune response in ducklings following oral immunisation with an attenuated duck enteritis virus vaccine. Vet. J. 2010, 185, 199-203. [CrossRef] [PubMed]

12. Xia, Y.; Jia, R.; Huang, J.; Shu, B.; Zhu, D.; Liu, Q.; Gao, X.; Meng, L.; Yin, Z.; Wang, M. Attenuated salmonella typhimurium delivering DNA vaccine encoding duck enteritis virus UL24 induced systemic and mucosal immune responses and conferred good protection against challenge. Vet. Res. 2012, 43, 56.

13. Sun, K.; Xin, L.; Jiang, J.; Cheng, A.; Wang, M.; Zhu, D.; Jia, R.; Chen, S.; Yi, Z.; Chen, X. Distribution characteristics of DNA vaccine encoded with glycoprotein $\mathrm{c}$ from anatid herpesvirus 1 with chitosan and liposome as deliver carrier in ducks. Virol. J. 2013, 10, 89. [CrossRef] [PubMed]

14. Qi, X.; Yang, X.; Cheng, A.; Wang, M.; Guo, Y.; Jia, R. Replication kinetics of duck virus enteritis vaccine virus in ducklings immunized by the mucosal or systemic route using real-time quantitative PCR. Res. Vet. Sci. 2009, 86, 63-67. [CrossRef] [PubMed]

15. Qi, X.F.; Cheng, A.C.; Wang, M.S.; Yang, X.Y.; Jia, R.Y.; Chen, X.Y. Induction of IGA, IGM and IGG antibodies in ducklings immunized with attenuated duck plague virus vaccine strain. Sci. Agric. Sin. 2008, 41, 3305-3310.

16. Anchun, C.; Mingshu, W.; Fei, L.; Yong, S.; Guiping, Y.; Xiaoying, H.; Chao, X.; Yonghong, L.; Ming, W.; Weiguang, Z. Distribution and excretion of duck plague virus attenuated cha strain in vaccinated ducklings. Chin. J. Vet. Sci. 2005, 25, 231-233.

17. Jorgensen, I.; Rayamajhi, M.; Miao, E.A. Programmed cell death as a defence against infection. Nat. Rev. Immunol. 2017, 17, 151-164. [CrossRef] [PubMed]

18. You, Y.; Cheng, A.C.; Wang, M.S.; Jia, R.Y.; Sun, K.F.; Yang, Q.; Wu, Y.; Zhu, D.; Chen, S.; Liu, M.F.; et al. The suppression of apoptosis by alpha-herpesvirus. Cell Death Dis. 2017, 8, e2749. [CrossRef] [PubMed]

19. Zheng, J.H.; Viacava Follis, A.; Kriwacki, R.W.; Moldoveanu, T. Discoveries and controversies in BCL-2 protein-mediated apoptosis. FEBS J. 2016, 283, 2690-2700. [CrossRef] [PubMed]

20. Shore, G.C.; Papa, F.R.; Oakes, S.A. Signaling cell death from the endoplasmic reticulum stress response. Curr. Opin. Cell Biol. 2011, 23, 143-149. [CrossRef] [PubMed]

21. Verma, G.; Datta, M. The critical role of JNK in the ER-mitochondrial crosstalk during apoptotic cell death. J. Cell. Physiol. 2012, 227, 1791-1795. [CrossRef] [PubMed]

22. Mates, J.M.; Segura, J.A.; Alonso, F.J.; Marquez, J. Oxidative stress in apoptosis and cancer: An update. Arch. Toxicol. 2012, 86, 1649-1665. [CrossRef] [PubMed]

23. Venditti, P.; Di Stefano, L.; Di Meo, S. Mitochondrial metabolism of reactive oxygen species. Mitochondrion 2013, 13, 71-82. [CrossRef] [PubMed]

24. Vakifahmetoglu-Norberg, H.; Ouchida, A.T.; Norberg, E. The role of mitochondria in metabolism and cell death. Biochem. Biophys. Res. Commun. 2017, 482, 426-431. [CrossRef] [PubMed]

25. Riley, J.S.; Malik, A.; Holohan, C.; Longley, D.B. Ded or alive: Assembly and regulation of the death effector domain complexes. Cell Death Dis. 2015, 6, e1866. [CrossRef] [PubMed]

26. Tummers, B.; Green, D.R. Caspase-8: Regulating life and death. Immunol. Rev. 2017, 277, 76-89. [CrossRef] [PubMed]

27. Guo, Y.; Shen, C.; Cheng, A.; Wang, M.; Zhang, N.; Chen, S.; Zhou, Y. Anatid herpesvirus 1 ch virulent strain induces syncytium and apoptosis in duck embryo fibroblast cultures. Vet. Microbiol. 2009, 138, 258-265. [CrossRef] [PubMed]

28. Guiping, Y.; Anchun, C.; Mingshu, W.; Xiaoying, H.; Yi, Z.; Fei, L. Preliminary study on duck enteritis virus-induced lymphocyte apoptosis in vivo. Avian Dis. 2007, 51, 546-549. [CrossRef]

29. Zhao, L.; Cheng, A.; Wang, M.; Yuan, G.; Cai, M. Characterization of codon usage bias in the dutpase gene of duck enteritis virus. Prog. Nat. Sci. Mater. Int. 2008, 18, 1069-1076. [CrossRef] 
30. Xin, H.Y.; Cheng, A.C.; Wang, M.S.; Jia, R.Y.; Shen, C.J.; Chang, H. Identification and characterization of a duck enteritis virus US3-like gene. Avian Dis. 2009, 53, 363-369. [CrossRef] [PubMed]

31. Yufei, G.; Anchun, C.; Mingshu, W.; Renyong, J.; Ming, W.; Weiguang, Z.; Xiaoyue, C. Establishment and application of quantitative real time pcr assay for detecting duck viral enteritis virus. Chin. J. Vet. Sci. 2006, 36, 444-448.

32. You, Y.; Liu, T.; Wang, M.; Cheng, A.; Jia, R.; Yang, Q.; Wu, Y.; Zhu, D.; Chen, S.; Liu, M.; et al. Duck plague virus glycoprotein $\mathrm{j}$ is functional but slightly impaired in viral replication and cell-to-cell spread. Sci. Rep. 2018, 8, 4069. [CrossRef] [PubMed]

33. Tsalenchuck, Y.; Steiner, I.; Panet, A. Innate defense mechanisms against HSV-1 infection in the target tissues, skin and brain. J. Neurovirol. 2016, 22, 641-649. [CrossRef] [PubMed]

34. Geiser, V.; Rose, S.; Jones, C. Bovine herpesvirus type 1 induces cell death by a cell-type-dependent fashion. Microb. Pathog. 2008, 44, 459-466. [CrossRef] [PubMed]

35. Yeh, C.J.; Lin, P.Y.; Liao, M.H.; Liu, H.J.; Lee, J.W.; Chiu, S.J.; Hsu, H.Y.; Shih, W.L. TNF- $\alpha$ mediates pseudorabies virus-induced apoptosis via the activation of p38 MAPK and JNK/SAPK signaling. Virology 2008, 381, 55-66. [CrossRef] [PubMed]

36. Longo, M.; Fiorito, F.; Marfe, G.; Montagnaro, S.; Pisanelli, G.; De Martino, L.; Iovane, G.; Pagnini, U. Analysis of apoptosis induced by caprine herpesvirus 1 in vitro. Virus Res. 2009, 145, 227-235. [CrossRef] [PubMed]

37. Gillis, P.A.; Okagaki, L.H.; Rice, S.A. Herpes simplex virus type 1 ICP27 induces p38 mitogen-activated protein kinase signaling and apoptosis in HeLa cells. J. Virol. 2009, 83, 1767-1777. [CrossRef] [PubMed]

38. Devireddy, L.R.; Jones, C.J. Activation of caspases and p53 by bovine herpesvirus 1 infection results in programmed cell death and efficient virus release. J. Virol. 1999, 73, 3778-3788. [PubMed]

39. Xu, X.; Zhang, K.; Huang, Y.; Ding, L.; Chen, G.; Zhang, H.; Tong, D. Bovine herpes virus type 1 induces apoptosis through fas-dependent and mitochondria-controlled manner in madin-darby bovine kidney cells. Virol. J. 2012, 9, 202. [CrossRef] [PubMed]

40. Hu, S.; Sheng, W.S.; Schachtele, S.J.; Lokensgard, J.R. Reactive oxygen species drive herpes simplex virus (hsv)-1-induced proinflammatory cytokine production by murine microglia. J. Neuroinflammation. 2011, 8 , 123. [CrossRef] [PubMed]

41. Schachtele, S.J.; Hu, S.; Lokensgard, J.R. Modulation of experimental herpes encephalitis-associated neurotoxicity through sulforaphane treatment. PLoS ONE 2012, 7, e36216. [CrossRef] [PubMed]

42. Kavouras, J.H.; Prandovszky, E.; Valyi-Nagy, K.; Kovacs, S.K.; Tiwari, V.; Kovacs, M.; Shukla, D.; Valyi-Nagy, T. Herpes simplex virus type 1 infection induces oxidative stress and the release of bioactive lipid peroxidation by-products in mouse p19n neural cell cultures. J. Neurovirol. 2007, 13, 416-425. [CrossRef] [PubMed]

43. Gonzalez-Dosal, R.; Horan, K.A.; Rahbek, S.H.; Ichijo, H.; Chen, Z.J.; Mieyal, J.J.; Hartmann, R.; Paludan, S.R. HSV infection induces production of ROS, which potentiate signaling from pattern recognition receptors: Role for S-glutathionylation of TRAF3 and 6. PLoS Pathog. 2011, 7, e1002250. [CrossRef] [PubMed]

44. Zhu, L.; Yuan, C.; Zhang, D.; Ma, Y.; Ding, X.; Zhu, G. Bhv-1 induced oxidative stress contributes to mitochondrial dysfunction in mdbk cells. Vet. Res. 2016, 47, 47. [CrossRef] [PubMed]

45. Murata, T.; Goshima, F.; Daikoku, T.; Inagaki-Ohara, K.; Takakuwa, H.; Kato, K.; Nishiyama, Y. Mitochondrial distribution and function in herpes simplex virus-infected cells. J. Gen. Virol. 2000, 81, 401-406. [CrossRef] [PubMed]

46. Kim, J.C.; Choi, S.H.; Kim, J.K.; Kim, Y.; Kim, H.J.; Im, J.S.; Lee, S.Y.; Choi, J.M.; Lee, H.M.; Ahn, J.K. Herpes simplex virus type $1 \mathrm{ICP} 27$ induces apoptotic cell death by increasing intracellular reactive oxygen species. Mol. Biol. 2008, 42, 470-477. [CrossRef]

47. Hobbs, W.E., 2nd; DeLuca, N.A. Perturbation of cell cycle progression and cellular gene expression as a function of herpes simplex virus ICP0. J. Virol. 1999, 73, 8245-8255. [PubMed]

48. Li, H.; Baskaran, R.; Krisky, D.M.; Bein, K.; Grandi, P.; Cohen, J.B.; Glorioso, J.C. CHK2 is required for hsv-1 ICP0-mediated G2/M arrest and enhancement of virus growth. Virology 2008, 375, 13-23. [CrossRef] [PubMed] 
49. Bringhurst, R.M.; Schaffer, P.A. Cellular stress rather than stage of the cell cycle enhances the replication and plating efficiencies of herpes simplex virus type 1 ICP0- viruses. J. Virol. 2006, 80, 4528-4537. [CrossRef] [PubMed]

50. Pagnini, U.; Montagnaro, S.; Sanfelice di Monteforte, E.; Pacelli, F.; De Martino, L.; Roperto, S.; Florio, S.; Iovane, G. Caprine herpesvirus-1 (CAPHV-1) induces apoptosis in goat peripheral blood mononuclear cells. Vet. Immunol. Immunopathol. 2005, 103, 283-293. [CrossRef] [PubMed]

51. Trapp-Fragnet, L.; Bencherit, D.; Chabanne-Vautherot, D.; Le Vern, Y.; Remy, S.; Boutet-Robinet, E.; Mirey, G.; Vautherot, J.F.; Denesvre, C. Cell cycle modulation by marek's disease virus: The tegument protein VP22 triggers s-phase arrest and DNA damage in proliferating cells. PLoS ONE 2014, 9, e100004. [CrossRef] [PubMed]

(C) 2019 by the authors. Licensee MDPI, Basel, Switzerland. This article is an open access article distributed under the terms and conditions of the Creative Commons Attribution (CC BY) license (http:/ / creativecommons.org/licenses/by/4.0/). 